\title{
Прісноводні голі амеби (Tubulinea, Discosea, Heterolobosea) Закарпатської області та прилеглих територій (Україна)
}

\section{Марина Пацюк, Олена Увасва}

Житомирський державний університет імені Івана Франка, Житомир, Україна Адреса для листування: kostivna@ukr.net

Отримано: 29.04.19; прийнято до друку: 20.05.19; опубліковано: 28.06.19

\begin{abstract}
Резюме. У водоймах Закарпатської області та прилеглих територій знайдено 19 видів голих амеб, які за сучасною системою належать до 3 -х класів, 8 родин та 12 родів. Це такі види: D. mycophaga, S. stagnicola, Saccamoeba sp. (2), Rhizamoeba sp. (1), Rhizamoeba sp. (2), K. stella, Vexillifera sp., V. lata, Vannella sp., Cochliopodium sp. (1), M. cantabrigiensis, M. vespertilioides, Mayorella sp. (1), T. striata, T. terricola, S. stenopodia, Acanthamoeba sp. (1), Vahlkampfia sp. (1), Vahlkampfia sp. (2). Знайдені нами види належать до 11 морфотипів: моноподіального, язикоподібного, стріатного, ругозного, лінзоподібного, віялоподібного, майорельного, дактилоподіального, акантоподіального, розгалуженого, еруптивного. На поширення голих амеб та їх морфотипів у водоймах Закарпатської області впливають гідрофізичні й гідрохімічні чинники середовища (температура, активна реакція водного середовища, концентрація розчиненого у воді кисню та концентрація розчинених у воді органічних речовин).

Ключові слова: голі амеби, морфотипи, абіотичні фактори, Закарпатська область.
\end{abstract}

\section{Freshwater Naked Amoebae (Tubulinea, Discosea, Heterolobosea) of the Zakarpattia Region and the Surrounding Areas (Ukraine)}

\section{Maryna Patsyuk, Olena Uvayeva}

Zhytomyr Ivan Franko State University, Zhytomyr, Ukraine Correspondence:e-mail: kostivna@ukr.net

\begin{abstract}
In water bodies of the Zakarpattia region and the surrounding areas we found 19 species of naked amoebae related to amoebae 3 classes, 8 families and 12 genera according to modern system. This species are: D. mycophaga, S. stagnicola, Saccamoeba sp. (2), Rhizamoeba sp. (1), Rhizamoeba sp. (2), K. stella, Vexillifera sp., V. lata, Vannella sp., Cochliopodium sp. (1), M. cantabrigiensis, M. vespertilioides, Mayorella sp. (1), T. striata, T. terricola, S. stenopodia, Acanthamoeba sp. (1), Vahlkampfia sp. (1), Vahlkampfia sp. (2). We found 11 species belong to the morphotypes: monotactic, lingulate, striate, rugose, lens-like, fan-shaped, mayorellian, dactylopodial, acanthopodial, branched, eruptive. Rhe distribution of naked amoebae and their morphotypes in waters of the Zakarpattia region is influenced by hydrophysical and hydrochemical factors of the environment (temperature, active reaction of water environment, the concentration of dissolved oxygen in the water and concentration of dissolved organic substances). It was found that 7 species of naked amoebae (Vexillifera sp., V. lata, Vannella sp., Cochliopodium sp. (1), Acanthamoeba sp. (1), Vahlkampfia sp. (1), Vahlkampfia sp. (2)) withstand the full range of temperatures (from $+16^{\circ} \mathrm{C}$ to $+18^{\circ} \mathrm{C}$ ); four species of amoebae were found in the range of values of the active reaction of the water environment from 5.8 to 7.7 (Rhizamoeba sp. (1), Cochliopodium sp. (1), Vahlkampfia sp. (1), Vahlkampfia sp. (2)), and these species form a group of evrione species; the entire range of values of dissolved oxygen in the water can withstand the species of Vahlkampfia sp. (2) and it can be considered euryoxidic; $T$. striata prefers a significant content of water-soluble organic substances (from $8.54 \mathrm{mg} \mathrm{O} / 1$ to $14.20 \mathrm{mg} \mathrm{O}_{2} / \mathrm{l}$ ).
\end{abstract}

Key words: naked amoebas, morphotypes, abiotic factors, Zakarpattia region. 


\section{Вступ}

Голі амеби - одноклітинні гетеротрофні організми, які є обов'язковими компонентами водних та грунтових біоценозів, що відрізняються видовою структурою й відіграють важливу трофічну роль. Дані про фауну голих амеб різних за умовами та географічно віддалених біотопів практично відсутні. Тому для отримання інформації щодо особливостей поширення цієї групи протистів потрібно вивчати проби 3 віддалених місцезнаходжень і порівнювати їх із видами, виявленими в складі локальних фаун [24].

На території України ми почали вивчати угруповання голих амеб у 2009 р. за матеріалами, які зібрано у водоймах Житомирського та Волинського Полісся [1-3, 11-14], згодом продовжили роботи й описали видовий склад амеб та особливості їх поширення у водоймах Київської, Рівненської, Сумської й Львівської областей $[4-7,15-17,19]$, а також у грунтах лісових зон Житомирської області [18]. Ми намагаємося вивчати населення голих амеб у різних біотопах із метою встановлення головних факторів, які визначають особливості ïx поширення. Уперше ми вивчили видовий склад голих амеб у водоймах Закарпатської області та прилеглих територій.

\section{Матеріал і методи дослідження}

Натурні дослідження проводили у 2018 р. у водоймах Закарпатської області та прилеглих територій. Для вивчення видового складу голих амеб здійснено дві експедиції. Усього за період дослідження проаналізовано близько 70 проб у 8 пунктах збору. Досліджено за допомогою сучасних методів світлової мікроскопії, зокрема диференційно-інтерференційного контрасту, до 150 особин голих амеб.

Проби (воду та скаламучені донні відклади) відбирали вручну в скляні посудини ємкістю до 500 мл і доставляли до лабораторії. Амеб виділяли $з$ проб, у які входили верхній шар донного грунту й невелика кількість придонної води. Розмноження амеб проводили в чашках Петрі діаметром 100 мм за методикою Пейджа [9-10]. Амеб підтримували в культурах при температурі $20{ }^{\circ} \mathrm{C}$. Спостереження за найпростішими та виготовлення мікрофотографій здійснювали за допомогою світлового мікроскопа Axio Imager MI (Центр колективного користування науковими приладами «Animalia» Інституту зоології ім. І.І.Шмальгаузена) із застосуванням диференційного інтерференційного контрасту, відсаджуючи живі клітини в краплі води на предметні скельця.

Ідентифікацію амеб здійснювали за два етапи - спочатку проводили визначення їx морфотипу за допомогою спеціальних праць [20, 23-24], після цього (якщо дозволяли дані) використовували таксономічний визначник Пейджа [9-10], як і більш пізні публікації із систематики голих амеб [20-24].

Сучасні методи дослідження не дають змогу отримати дані щодо чисельності голих амеб, тому ми аналізували частоту трапляння цих протистів у досліджуваних водоймах.

При відборі проб визначали основні фізикохімічні показники досліджуваних водойм: температуру, активну реакцію водного середовища, концентрацію розчиненого у воді кисню та концентрацію розчинених у воді органічних речовин (за перманганатною окислюваністю) [8].

\section{Результати дослідження}

У досліджуваних водоймах ідентифіковано 19 видів голих амеб, які належать до 3-х класів, 8 родин та 12 родів [24].

\section{Клас Tubulinea Smirnov et al., 2005}

Ряд Tubulinida Smirnov et al., 2005

Родина Amoebidae Ehrenberg, 1838

Рід Deuteramoeba Page, 1987

Deuteramoeba mycophaga (Pussard, Alabouvette, Lemaitre \& Pons, 1980) Page, 1988

Родина Hartmannellidae (Volkonsky, 1931) Page, 1974

Рід Sассатоеbа Frenzel, 1892

Saccamoeba stagnicola Page, 1974

Saccamoeba sp. (2)

Ряд Leptomyxida (Pussard \& Pons, 1976) Page, 1987

Родина Leptomyxidae (Pussard \& Pons, 1976) Page, 1987

Рід Rhizamoeba Page, 1972

Rhizamoeba sp. (1)

Rhizamoeba sp. (2)

Клас Discosea Cavalier-Smith et al., 2004

Підклас Flabellinia Smirnov et al., 2005

Ряд Dactylopodida Smirnov et al., 2005

Родина Paramoebidae Poche,1913

Рід Korotnevella Page, 1981

Korotnevella stella (Schaeffer, 1926) Goodkov, 1988

Родина Vexilliferidae Page, 1987 
Рід Vexillifera Schaeffer, 1926

Vexillifera sp.

Ряд Vannellida Smirnov et al., 2005

Родина Vannellidae Bovee, 1979

Рід Vannella Bovee, 1965

Vannella lata Page, 1988

Vannella sp.

Ряд Himatismenida Page, 1987

Родина Cochliopodiidae De Saedeleer, 1934

Рід Cochliopodium Hertwig \& Lesser, 1874

Cochliopodium sp. (1)

Підклас Longamoebia Smirnov, Nassonova, Chao

et Cavalier-Smith, 2011

Ряд Dermamoebida Cavalier-Smith, 2004

Родина Mayorellidae Schaeffer, 1926

Рід Mayorella Schaeffer, 1926

Mayorella cantabrigiensis Page, 1983

Mayorella vespertilioides Page, 1983

Mayorella sp. (1)

Ряд Thecamoebida Smirnov, Nassonova, Chao et

Cavalier-Smith, 2011

Родина Thecamoebidae Schaeffer,1926

Рід Thecamoeba Fromentel, 1874

Thecamoeba striata (Penard, 1890) Schaeffer, 1926

Thecamoeba terricola (Greef, 1866) Lepsi, 1960

Рід Stenamoeba Smirnov et al., 2007

Stenamoeba stenopodia (Page, 1969) Smirnov et al., 2007

Ряд Centramoebida Rogerson and Patterson, 2002

Родина Acanthamoebidae Sawyer and Griffin, 1975

Рід Acanthamoeba Volkonsky, 1931

Acanthamoeba sp. (1)

\section{Клас Heterolobosea Page et Blanton, 1985}

Родина Vahlkampfiidae Jollos, 1917

Рід Vahlkampfia Chatton \& Lalung-Bonnaire, 1912

Vahlkampfia sp. (1)

Vahlkampfia sp. (2)

Найбільшу кількість видів голих амеб у водоймах Закарпатської області та прилеглих територій відзначено для групи Discosea (12 видів), найменша - для групи Heterolobosea (2 види), Tubulinea - нараховує 5 видів амеб.

Як видно 3 табл. 1, шість видів голих амеб знайдено в половині досліджуваних водойм, що становить 31,6 \% від усього видового списку амеб. Частота трапляння цих видів у пробах така: Vexillifera sp. 52,3 \%, V. lata 48,3\%, Cochliopodium sp. (1) 48,7\%, Acanthamoeba sp. (1) 51,4 \%, Vahlkampfia sp. (1) 47,2 \%, Vahlkampfia sp. (2) 46,4\%. Близько 42,1\% видів амеб відзначено лише у двох водоймах дослідження і займають середнє положення за частотою трапляння. 26,3\% голих амеб від усієї кількості знайдених видів спостерігали лише в одній із досліджуваних водойм, що може бути пов'язано 3 їх рідкісністю та нечисельністю (частота трапляння цих видів у водоймах становить менше $10 \%$ ).

За весь період дослідження у водоймах досліджуваних регіонів виявлено порівняно велике видове багатство амеб у заплавній водоймі біля м. Ужгород (9 видів), р. Ріка біля c. Березово (10 видів) та р. Теребля поблизу c. Синевирська Поляна (11 видів) (табл. 1). Найменшим видовим складом голих амеб характеризуються оз. Синевир та р. Луква біля м. Івано-Франківськ (по 2 види відповідно). Крім того, в оз. Синевир нами виявлено Rhizamoeba sp. (2), яка в попередніх дослідженнях реєструвалася лише у водоймах ШНПП [3], що, імовірно, пов'язано 3 подібними гідрохімічними умовами досліджуваних озер, які $є$ оптимальними для існування цієї амеби.

Під час дослідження видового складу голих амеб у водоймах Закарпатської області та прилеглих територій ми реєстрували гідрофізичні та гідрохімічні параметри водойм. Нами оцінено ті значення чинників середовища, при яких спостерігали певні види амеб (табл. 2). Збір матеріалу проводили в літній період року (2018 р.). Температура досліджуваних водойм коливалась від $+16{ }^{\circ} \mathrm{C}$ до $+18^{\circ} \mathrm{C}$; $\mathrm{pH}$ води - від 5,8 до 7,8; уміст розчиненого у воді кисню - від 7,32 мг/л до 12,03 мг/л; уміст розчинених у воді органічних речовин - від 8,54 мг $\mathrm{O}_{2} /$ л до 14,2 мг $\mathrm{O}_{2} /$ л. Сім видів голих амеб (36,8 \% від загальної кількості видів) витримують увесь діапазон значень температури (табл. 2); чотири види амеб знайдено в діапазоні значень активної реакції водного середовища від 5,8 до 7,7 і ці види утворюють групу евриіонних видів (21 \% від загальної кількості видів); увесь діапазон значень розчиненого у воді кисню витримує вид Vahlkampfia sp. (2) і його можна вважати евриоксидним; $T$. striata надає перевагу значному вмісту у воді органічних речовин (від 8,54 мг $\mathrm{O}_{2} /$ л до 14,20 мг $\mathrm{O}_{2} /$ л). Це підтверджують попередні наші дослідження щодо впливу абіотичних факторів водного середовища на поширення голих амеб у водоймах України [13].

Що ж стосується мофротипів голих амеб, то, за нашими даними, у досліджуваних водоймах виявлено амеб, які належать до 11 морфотипів (табл. 3). Найбільшим різноманіттям морфо- 
Прісноводні голі амеби (Tubulinea, Discosea, Heterolobosea) Закарпатської області та прилеглих територій (Украӥна)

Таблиия 1

Поширення голих амеб у водоймах Закарпатської області та прилеглих територій («+»- вид є, «-»- виду немає)

\begin{tabular}{|c|c|c|c|c|c|c|c|c|c|}
\hline \multirow[b]{2}{*}{ № } & \multirow[b]{2}{*}{ Вид амеб } & \multicolumn{8}{|c|}{ Пункти збору } \\
\hline & & $\begin{array}{c}\text { болото } \\
\text { біля } \\
\text { м. Ужго- } \\
\quad \text { род }\end{array}$ & $\begin{array}{c}\text { заплавна } \\
\text { водойма } \\
\text { біля } \\
\text { м. Ужго- } \\
\text { род }\end{array}$ & $\begin{array}{c}\text { р. Ріка } \\
\text { біля } \\
\text { с. Бере- } \\
\text { зово }\end{array}$ & $\begin{array}{c}\text { р. Теребля } \\
\text { біля } \\
\text { с. Сине- } \\
\text { вирська } \\
\text { Поляна }\end{array}$ & $\begin{array}{c}\text { оз. } \\
\text { Сине- } \\
\text { вир }\end{array}$ & $\begin{array}{c}\text { р. Дуба } \\
\text { біля } \\
\text { с. Дуба } \\
\text { Івано- } \\
\text { Франків- } \\
\text { ського } \\
\text { району }\end{array}$ & $\begin{array}{c}\text { заплавна } \\
\text { водойма } \\
\text { біля } \\
\text { м. Івано- } \\
\text { Фран- } \\
\text { ківськ }\end{array}$ & $\begin{array}{l}\text { р. Луква } \\
\text { біля } \\
\text { м. Івано- } \\
\text { Фран- } \\
\text { ківськ }\end{array}$ \\
\hline 1 & D. mycophaga & - & - & - & - & - & + & - & - \\
\hline 2 & S. stagnicola & - & + & + & - & - & - & - & + \\
\hline 3 & $\begin{array}{l}\text { Saccamoeba } \\
\text { sp. (2) }\end{array}$ & - & - & + & - & - & + & - & - \\
\hline 4 & $\begin{array}{l}\text { Rhizamoeba } \\
\text { sp. (1) }\end{array}$ & + & + & - & - & - & - & - & - \\
\hline 5 & $\begin{array}{l}\text { Rhizamoeba } \\
\text { sp. (2) }\end{array}$ & - & - & - & + & - & - & - & - \\
\hline 6 & K. stella & - & + & - & - & - & - & - & - \\
\hline 7 & Vexillifera $\mathrm{sp}$. & - & + & + & + & - & - & + & - \\
\hline 8 & V. lata & - & + & + & + & - & - & + & - \\
\hline 9 & Vannella sp. & - & - & - & + & - & - & + & - \\
\hline 10 & $\begin{array}{l}\text { Cochliopo- } \\
\text { dium sp. (1) }\end{array}$ & + & + & + & + & - & - & - & - \\
\hline 11 & $\begin{array}{c}M . \\
\text { cantabrigiensis }\end{array}$ & - & - & + & + & - & - & - & - \\
\hline 12 & $\begin{array}{c}\text { M. } \\
\text { vespertilioides }\end{array}$ & - & - & + & - & - & - & - & - \\
\hline 13 & $\begin{array}{l}\text { Mayorella sp. } \\
\text { (1) }\end{array}$ & - & - & + & - & - & - & - & - \\
\hline 14 & T. striata & - & - & - & - & + & - & + & - \\
\hline 15 & T. terricola & - & - & - & + & + & - & - & - \\
\hline 16 & S. stenopodia & - & + & - & + & - & - & - & - \\
\hline 17 & $\begin{array}{l}\text { Acanthamoeba } \\
\text { sp. (1) }\end{array}$ & & - & - & + & - & + & + & + \\
\hline 18 & $\begin{array}{l}\text { Vahlkampfia } \\
\text { sp. (1) }\end{array}$ & + & + & + & + & - & + & - & - \\
\hline 19 & $\begin{array}{l}\text { Vahlkampfia } \\
\text { sp. (2) }\end{array}$ & + & + & + & + & - & - & + & - \\
\hline & Усього & 4 & 9 & 10 & 11 & 2 & 4 & 6 & 2 \\
\hline
\end{tabular}


Науковий вісник Східноєвропейського національного університету імені Лесі Украӥнки. Серія: Біологічні науки, 2019, 3 (387)

Табличя 2

Гідрофізична й гідрохімічна характеристика біотопів голих амеб досліджуваних водойм

\begin{tabular}{|c|c|c|c|c|c|}
\hline $\begin{array}{c}\text { № } \\
\text { 3/II }\end{array}$ & Вид амеб & Температура, ${ }^{\circ} C$ & pH & $\begin{array}{c}\text { Уміст } \\
\text { розчиненого } \\
\text { у воді кисню, }, \text { м2/л }\end{array}$ & $\begin{array}{c}\text { Уміст розчинених } \\
\text { у воді органічних } \\
\text { речовин, } \\
\text { мг } O_{2} / л \\
\end{array}$ \\
\hline 1 & D. mycophaga & 17 & 7,3 & 10,20 & 11,15 \\
\hline 2 & S. stagnicola & $16-17,5$ & $7,2-7,8$ & $9,82-11,02$ & $9,32-12,05$ \\
\hline 3 & Saccamoeba sp. (2) & $16-17$ & $7,3-7,7$ & 10,20 & $11,5-12,05$ \\
\hline 4 & Rhizamoeba sp. (1) & $17,5-18$ & $5,8-7,2$ & $7,32-9,82$ & $10,80-12,03$ \\
\hline 5 & Rhizamoeba sp. (2) & 16 & 7,4 & 10,42 & 9,63 \\
\hline 6 & K. stella & 17,5 & 7,2 & 9,82 & 12,03 \\
\hline 7 & Vexillifera sp. & $16-18$ & $7,2-7,7$ & $9,82-12,03$ & $9,63-12,05$ \\
\hline 8 & V. lata & $16-18$ & $7,2-7,7$ & $9,82-12,03$ & $9,63-14,20$ \\
\hline 9 & Vannella sp. & $16-18$ & $7,25-7,4$ & $10,42-12,03$ & $9,63-14,20$ \\
\hline 10 & Cochliopodium sp. (1) & $16-18$ & $5,8-7,7$ & $7,32-10,42$ & $9,63-12,05$ \\
\hline 11 & M. cantabrigiensis & 16 & $7,4-7,7$ & $10,20-10,42$ & $9,63-12,05$ \\
\hline 12 & M. vespertilioides & 16 & 7,7 & 10,20 & 12,05 \\
\hline 13 & Mayorella sp. (1) & 16 & 7,7 & 10,20 & 12,05 \\
\hline 14 & T. striata & $17,5-18$ & $7,25-7,3$ & $11,05-12,03$ & $8,54-14,20$ \\
\hline 15 & T. terricola & $16-17,5$ & $7,3-7,4$ & $10,42-11,05$ & $8,54-9,63$ \\
\hline 16 & S. stenopodia & $16-17,5$ & $7,2-7,4$ & $9,82-10,42$ & $9,63-12,03$ \\
\hline 17 & Acanthamoeba sp. (1) & $16-18$ & $7,25-7,8$ & $10,20-11,02$ & $9,32-14,20$ \\
\hline 18 & Vahlkampfia sp. (1) & $16-18$ & $5,8-7,7$ & $7,32-10,42$ & $9,63-12,05$ \\
\hline 19 & Vahlkampfia sp. (2) & $16-18$ & $5,8-7,7$ & $7,32-12,03$ & $9,63-14,20$ \\
\hline
\end{tabular}

Таблиия 3

Поширення морфотипів голих амеб у водоймах Закарпатської області та прилеглих територій («+»- морфотип $\epsilon$, «-»- морфотипу немає)

\begin{tabular}{|c|c|c|c|c|c|c|c|c|c|}
\hline \multirow[b]{2}{*}{ № } & \multirow[b]{2}{*}{$\begin{array}{l}\text { Морфотипи } \\
\text { голих амеб }\end{array}$} & \multicolumn{8}{|c|}{ Пункти збору } \\
\hline & & $\begin{array}{c}\text { болото } \\
\text { біля } \\
\text { м. Ужго- } \\
\text { род }\end{array}$ & $\begin{array}{c}\text { заплавна } \\
\text { водойма } \\
\text { біля } \\
\text { м. Ужго- } \\
\text { род }\end{array}$ & $\begin{array}{c}\text { р. Ріка } \\
\text { біля } \\
\text { с. Бере- } \\
\text { зово }\end{array}$ & $\begin{array}{c}\text { р. Тереб- } \\
\text { ля біля } \\
\text { с. Сине- } \\
\text { вирська } \\
\text { Поляна }\end{array}$ & \begin{tabular}{|c} 
оз. \\
Синевир
\end{tabular} & \begin{tabular}{|c} 
р. Дуба \\
біля \\
с. Дуба \\
Івано- \\
Франківсь \\
-кого \\
району
\end{tabular} & $\begin{array}{c}\text { заплавна } \\
\text { водойма } \\
\text { біля } \\
\text { м. Івано- } \\
\text { Фран- } \\
\text { ківськ }\end{array}$ & $\begin{array}{c}\text { р. Луква } \\
\text { біля } \\
\text { м. Івано- } \\
\text { Фран- } \\
\text { ківськ }\end{array}$ \\
\hline 1 & Моноподіальний & - & + & + & - & - & + & - & + \\
\hline 2 & Язикоподібний & - & + & - & + & - & - & - & - \\
\hline 3 & Стріатний & - & - & - & - & + & - & + & - \\
\hline 4 & Ругозний & - & - & - & + & + & - & - & - \\
\hline 5 & Лінзоподібний & + & + & + & + & - & - & - & - \\
\hline 6 & Віялоподібний & - & + & + & + & - & - & + & - \\
\hline 7 & Майорельний & - & - & + & + & - & - & - & - \\
\hline 8 & $\begin{array}{c}\text { Дактилоподі- } \\
\text { альний } \\
\end{array}$ & - & + & + & + & - & - & + & - \\
\hline 9 & $\begin{array}{c}\text { Акантоподіаль- } \\
\text { ний } \\
\end{array}$ & - & - & - & + & - & + & + & + \\
\hline 10 & Розгалужений & + & + & - & + & - & - & - & - \\
\hline 11 & Еруптивний & + & + & + & + & - & + & + & - \\
\hline & Усього & 3 & 7 & 6 & 9 & 2 & 3 & 5 & 2 \\
\hline
\end{tabular}


Прісноводні голі амеби (Tubulinea, Discosea, Heterolobosea) Закарпатської області та прилеглих територій (Украӥна)

Табличя 4

Гідрофізична й гідрохімічна характеристика біотопів голих амеб відповідних мофротипів досліджуваних водойм

\begin{tabular}{|c|c|c|c|c|c|}
\hline $\begin{array}{c}\text { № } \\
\text { 3/II }\end{array}$ & $\begin{array}{c}\text { Морфотипи голих } \\
\text { амеб }\end{array}$ & Tемпература, ${ }^{o} \mathrm{C}$ & $\mathbf{p H}$ & $\begin{array}{c}\text { Уміст } \\
\text { розчиненого } \\
\text { у воді кисню, } \\
\text { мг/л }\end{array}$ & $\begin{array}{c}\text { Уміст розчинених } \\
\text { у воді органічних } \\
\text { речовин, } \\
\text { мг } O_{2} / л\end{array}$ \\
\hline 1 & Моноподіальний & $16-17,5$ & $7,2-7,8$ & $9,82-11,02$ & $9,32-12,05$ \\
\hline 2 & Язикоподібний & $16-17,5$ & $7,2-7,4$ & $9,82-10,42$ & $9,63-12,03$ \\
\hline 3 & Стріатний & $17,5-18$ & $7,25-7,3$ & $11,05-12,03$ & $8,54-14,20$ \\
\hline 4 & Ругозний & $16-17,5$ & $7,3-7,4$ & $10,42-11,05$ & $8,54-9,63$ \\
\hline 5 & Лінзоподібний & $16-18$ & $5,8-7,7$ & $7,32-10,42$ & $9,63-12,05$ \\
\hline 6 & Віялоподібний & 17,5 & 7,2 & 9,82 & 12,03 \\
\hline 7 & Майорельний & 16 & $7,4-7,7$ & $10,20-10,42$ & $9,63-12,05$ \\
\hline 8 & Дактилоподіальний & $16-18$ & $7,2-7,7$ & $9,82-12,03$ & $9,63-14,20$ \\
\hline 9 & Акантоподіальний & $16-18$ & $7,25-7,8$ & $10,20-12,03$ & $9,32-14,20$ \\
\hline 10 & Розгалужений & $16-18$ & $5,8-7,4$ & $7,32-10,42$ & $9,63-12,03$ \\
\hline 11 & Еруптивний & $16-18$ & $5,8-7,7$ & $7,32-12,03$ & $9,63-14,20$ \\
\hline
\end{tabular}

типів характеризуються p. Теребля біля с. Синевирська Поляна (дев'ять морфотипів), заплавна водойма біля м. Ужгород (сім морфотипів), р. Ріка біля с. Березово (шість морфотипів), найменшим - оз. Синевир (два морфотипи), р. Луква біля м. ІваноФранківськ (два морфотипи) (табл. 3).

Два види голих амеб (Vahlkampfia sp. (1), Vahlkampfia sp. (2)) належать до еруптивного морфотипу й виявлені майже в усіх досліджуваних водоймах (табл. 3), що становить 9,1 \% від усіх знайдених морфотипів. Амеби моноподіального (D. mycophaga, S. stagnicola, Saccamoeba sp. (2)), язикоподібного (S. stenopodia), стріатного (T. striata), ругозного (T. terricola), лінзоподібного (Cochliopodium sp. (1)), віялоподібного (V. lata, Vannella sp.), майорельного (M.cantabrigiensis, M. vespertilioides, Mayorella sp. (1)), дактилоподіального (K. stella, Vexillifera sp.), акантоподіального (Acanthamoeba sp. (1)), розгалуженого (Rhizamoeba sp. (1), Rhizamoeba sp. (2)) морфотипів були знайдені у 2-х і більше водоймах досліджуваного регіону, що становить 90,9 \% від загальної кількості морфотипів. Амеби лінзоподібного, дактилоподіального, акантоподіального, розгалуженого та еруптивного морфотипів зареєстровані в усьому діапазоні значень температури (від $+16{ }^{\circ} \mathrm{C}$ до $+18{ }^{\circ} \mathrm{C}$ ); амеби лінзоподібного, розгалуженого та еруптивного морфотипів були знайдені при рН середовища від 5,8 до 7,7; амеби еруптивного морфотипу реєструвалися при концентрації розчиненого у воді кисню від 7,32 мг/л до 12,03 мг/л; амеби стріатного морфотипу витримують увесь діапазон значень умісту розчинених у воді органічних речовин 8,54-14,20 мг $\mathrm{O}_{2} /$ л $\quad$ (табл. 4). Значення абіотичних факторів досліджуваних водойм Закарпатської області та прилеглих територій, при яких реєструвались інші види амеб та їх морфотипи, наведено в табл. 2; 4. Відзначемо, що можливі знахідки видів, які стосуються того чи іншого морфотипу в інших умовах. Приналежність певних морфотипів до конкретного комплексу умов свідчить про те, що види 3 цими морфотипами значно більш численні при цих умовах, які, певно, $€$ близькими до оптимальних.

\section{Висновки}

У пробах із водойм Закарпатської області та прилеглих територій нами виявлено 19 видів голих амеб, які за сучасною системою голих амеб належать до 3 -х класів, 8 родин та 12 родів. На поширення голих амеб і їх морфотипів впливають температура, активна реакція водного середовища, уміст розчинених у воді кисню й органічних речовин. Ідентифіковані нами види належать до 11 морфотипів. 


\section{Література}

1. Пацюк, М. К. Голі лобозні амеби (Lobosea, Gymnamoebia) деяких водойм околиць м. Радомишль. Наукові записки Тернопільського Національного педагогічного університету імені Володимира Гнатюка. Серія: Біологія. Спец.. вип.: Гідроекологія; 2010, 2 (43), 390-395.

2. Пацюк, М. К. Виявлення голих амеб в озері Світязь. Наукові записки Тернопільського Національного педагогічного університету імені Володимира Гнатюка. Серія: Біологія; 2011, 3 (48), 27-30.

3. Пацюк, М. К. Голі амеби Шацьких озер. Природа Західного Полісся та прилеглих територій: зб. наук. праць/за заг. ред. Ф. В. Зузука, Луцьк: Східноєвроп. нац. ун-т ім. Лесі Українки, 2014, 11, 239-243.

4. Пацюк, М. К. Голі амеби фауни Київського Полісся. Наукові записки Тернопільського Національного педагогічного університету імені Володимира Гнатюка. Серія: Біологія; 2014, 2 (59), 49-52.

5. Пацюк, М. К. Голі амеби фауни Рівненської області. Природа Західного Полісся та прилеглих територій: зб. наук. праць/за заг. ред. Ф. В. Зузука, Луцьк: Східноєвроп. нац. ун-т ім. Лесі Українки, 2015, 12, 154-157.

6. Пацюк, М. К. Просторовий розподіл голих амеб у донному грунті стоячої водойми поблизу м. Дніпро (Україна). Природа Західного Полісся та прилеглих територій: зб. наук. праць/ за заг. ред. Ф. В. Зузука, Луцьк: Східноєвроп. нац. ун-т ім. Лесі Українки, 2017, 7 (356), 128-133.

7. Пацюк, М. К. Видовий склад і поширення голих амеб (Tubulinea, Discosea, Heterolobosea) у водоймах Львівської області. Вісник Львівського університету. Серія біологічна; 2018, 79, 141-149. doi.org/10.1515/vzoo-2015-0043

8. Строганов, Н. С.; Бузинова, Н. С. Практическое руководство по гидрохимии, Изд-во Моск. ун-та.: Москва; 1980; 196 с.

9. Page, F. C. A New Key to Freshwater and Soil Gymnamoebea. Freshwater Biological Association, Ambleside, Cumbria, UK, 1988; 122 p.

10. Page, F. C.; Siemensma, F. J. Nackte Rhizopoda und Heliozoea (Protozoenfauna Band 2). Gustav Fischer Verlag, Stuttgart, New York, 1991; 3-170.

11. Patcyuk, M. K. New Gymnamoebae species (Gymnamoebia) in the fauna of Ukraine. Vestnik zoologii; 2012, 46 (2), 105-111. DOI: 10.2478/v10058012-0010-4
12. Patsyuk, M. K.; Dovgal I. V. Biotopic distribution of naked amoebes (Protista) in Ukrainian Polissya area. Vestnik zoologii; 2012, 46 (4), 355-360. DOI:10.2478/v10058-012-0028-7

13. Patsyuk, M. K. Tolerance of Naked Amoebas (Protista) to the Abiotic Factors. Nature Montenegrina, Podgorica; 2013, 12 (2), 319-323.

14. Patsyuk, M. K. Morphotypes in Naked Amoebas (Protista): Distribution in Water Bodies of Zhytomyr and Volyn Polissia (Ukraine) and Possible Ecological Significance. Vestnik zoologii; 2014, 48 (6), 547-552. DOI: $10.2478 /$ vzoo-2014-0065

15. Patsyuk, M. K. Species of naked amoeba (Protista) new for the fauna of Ukraine. Vestnik zoologii; 2015, 49 (2), pp 451-456. doi.org/10.1515/vzoo-2015-0043

16. Patsyuk, M. K. Seasonal changes in the species composition of naked amoebas (Amoebina) of the Teterev river (the Town of Zhitomir). Hydrobiological Jornal; 2016, 52 (4), 55-62. DOI: 10.1615/HydrobJ.v52.i4.60

17. Patsyuk, M. K. Parasitic Amoebae Found in Water Bodies of Ukraine. Experimental parasitology; 2017, 183, 81-84. doi.org/10.1016/j.exppara.2017. 10.010

18. Patsyuk, M. K. First Findings of Naked Amoebae in Soils of Zhytomyr Polyssia (Ukraine). VII International Symposium of Ecologists of Montenegro. The Book of Abstracts and Programme, Montenegro, 2017, p 47.

19. Patsyuk, M. K. Peculiarities of the Spatial Distribution of Naked Amoebas in Sandy Bottom Sediments of a Small River. Hydrobiological Jornal; 2018, 54 (5), pp 102-111. DOI: 10.1615/HydrobJ. v54.i5.100

20. Smirnov, A.; Goodkov, A. An illustrated list of basic morphotypes of Gymnamoebae (Rhizopoda, Lobosea). Protistology; 1999, 1, pp 20-29.

21. Smirnov, A. V.; Goodkov, A. V. Ultrastructure and geographic distribution of genus Paradermamoeba (Gymnamoebia, Thecamoebidae). European Journal of Protistology; 2004, 40, pp 113-118. DOI: 10.1016/j.ejop.2003.12.001

22. Smirnov, A.; Nassonova, E.; Chao, E.; CavalierSmith, T. Phylogeny, Evolution, and Taxonomy of Vannellid Amoebae. Protist; 2007, 158, pp 295-324. DOI:10.1016/j.protis.2007.04.004

23. Smirnov, A. Amoebas, Lobose. Encyclopedia of Microbiology. M. Schaechter (ed.). Elsevier: Oxford, 2008; pp 558-577.

24. Smirnov, A.; Nassonova, E.; Chao, E.; CavalierSmith, T. A Revised Classification of Naked Lobose Amoebae (Amoebozoa: Lobosa). Protist, 2011, 162, pp 545-570. DOI:10.1016/j.protis.2011.04.004 